\title{
Investigation of Academic Self Efficacy of University Students in the Sports Area
}

\section{Çalık Veli KOÇAK ${ }^{1}$ Umut CANLI ${ }^{2}$ (D)}

'Hitit University, Faculty of Sports Science, Department of Physical Education and Sports Education, Turkey Email:kocakveli@hotmail.com

${ }^{2}$ Namık Kemal University, School of Physical Education and Sports, Department of Physical Education and Sports Education, Turkey

Email:umutcanli@hotmail.com

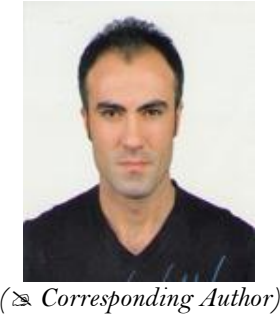

Abstract

The purpose of this research; was to investigate the academic self-efficacy of the university students studying in the field of sports according to various variables. The sample group of the study consisted of 386 (female, $42.7 \%$ male, 57.3\%) volunteer university students who were educated in physical education and sports teaching, sports management and coaching education departments by convenience sampling method. In order to collect the necessary information, a personal information form was used to determine the demographic characteristics of the participants and "Academic SelfEfficacy Scale", which was conducted by Ekici (2012) was used for Turkish validity and reliability study. Kolmogorov-Smirnov test was applied to determine whether the data showed normal distribution. In the analysis of the data, independent sample $t$ test was applied according to gender variable. One-Way ANOVA test was used in the analysis of the place where the participants' grew up, age, university, department, class variables and LSD test was used to determine the significant difference. Pearson Correlation test was used to determine the relationship between academic selfefficacy sub-dimensions and a significant relationship was found. As a result of the study, while there were no differences in terms of gender, age, university and department variables in academic selfefficacy subscales, a significant difference was found in the place where their families lived and class variables. When the results of the study were evaluated; it can be said that demographic variables are not an important factor in academic self-efficacy of the students.

Keywords: Academic self-efficacy, University students, Physical education and sports

JEL Classification: I29.

Citation | Çalık Veli KOÇAK; Umut CANLI (2019). Investigation of Academic Self Efficacy of University Students in the Sports Area. Asian Journal of Education and Training, 5(1): 56-62. History:

Received: 5 October 2018

Revised: 13 November 2018

Revised: 13 November 2018

Published: 3 January 2019

Licensed: This work is licensed under a Creative Commons Attribution 3.0 License (cc) I E

Publisher: Asian Online Journal Publishing Group
Contribution/Acknowledgement: Both authors contributed to the conception and design of the study.

Funding: This study received no specific financial support

Competing Interests: The authors declare that they have no conflict of interests.

Transparency: The authors confirm that the manuscript is an honest, Transparency: The authors confirm that the manuscript is an honest,
accurate, and transparent account of the study was reported; that no vital features of the study have been omitted; and that any discrepancies from the features of the study have been omitted;
study as planned have been explained.

Ethical: This study follows all ethical practices during writing.

\section{Contents}

1. Introduction ....................... 57

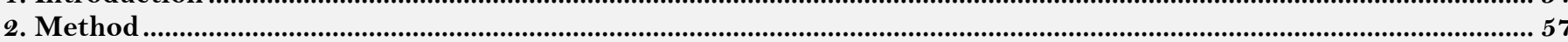

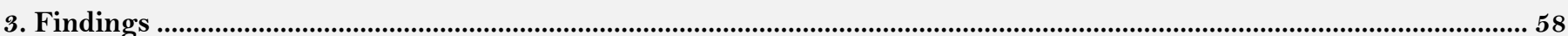

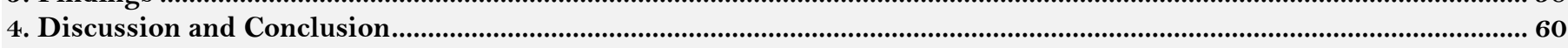

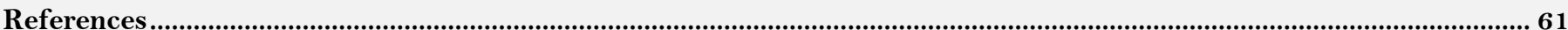




\section{Introduction}

The ideas that people have gained through their experiences throughout their lives affect their ability to carry out or not to carry out the same actions in the following years. Besides, people's beliefs and trusts about their abilities are shaped by their activities. In other words, the knowledge and skills that people possess are behavioural according to their beliefs about their abilities and capacities (Çubukçu and Girmen, 2007).

\subsection{Self-Efficacy}

Considering the conceptual aspect of "Self-efficacy", which Bandura (1982) included in Social Cognitive Theory; it is defined as the individual's trust in own abilities to do business individually (Kurbanoğlu, 2004). Self-efficacy beliefs lead people's behaviours to be related to self-esteem and ability perception. People think whether they will be successful in their job or not as to their abilities. Sometimes they might think they're facing a number of constraints (Koçak, 2017a; Koçak, 2017b). On the other hand, there are some characteristics that make self-efficacy and self-confidence different from each other. The self-confidence of people refers to the awareness of the talent or potential they have. The concept of self-efficacy refers to the perception whether the potential of people can be transformed into a performance (İpek and Bayraktar, 2009).

Self-efficacy belief has an important place in the behaviours of people. Individuals with high self-efficacy beliefs have high levels of responsibility for solving the problems they face, whereas people with low self-efficacy are often less likely to take responsibility for solving the problems they face. Besides, it is stated that individuals with high self-efficacy belief will have a better career line in their professional life (Belgi, 2016).

Wood and Bandura (1989) stated that individual's self-efficacy belief is nourished from certain sources and they sorted these resources from the most effective to the least effective as; "direct experiences", "indirect experiences", "social or verbal persuasion" and "emotional state".

Another factor that influences self-efficacy development is education (Schwarzer and Hallum, 2008). Bandura (1982) stated that; self-efficacy belief affects choices of individual's activities, level of efforts, resilience against difficulties and performance.

\subsection{Academic Self-Efficacy}

Bandura (1997) defined the academic self-efficacy belief; is to plan the whole of the actions necessary for the educational achievements previously planned and defined as the judgement related to capacity to carry out these actions.

In general, academic self-efficacy is considered as an affective element affecting academic achievement (Ekici, 2012). Students' efficacy beliefs related to their skills ease the ability of students to perform academic tasks such as preparing for the exam, doing homework or preparing projects successfully, and form a part of their academic lives. At this point, it is important to determine the self-efficacy belief that can help students in their academic tasks (Kandemir and Özbay, 2012).

Schunk (1991) listed the factors affecting the academic self-efficacy belief as follows:

Targeting: Determining targets and feedback are important cognitive processes in influencing self-efficacy.

Data Processing: The practices by the teacher in these processes have a great effect on the learning and selfefficacy belief of the student.

Role Models: Modelling as a result of observation affects the self-efficacy belief of the student.

Feedback: Source, timing, reliability and level are important for self-efficacy belief.

Awards: The awards associated with the student's success.

Bassi et al. (2007) reported that students who have high academic self-efficacy beliefs are more willing to perform academic tasks than low students. Likewise, it is stated that students with high academic self-efficacy beliefs perform more successfully in academic tasks than students with low self-efficacy beliefs (Edmonds, 2002). Academic self-efficacy and motivation are the determinants of academic performance. Academic self-efficacy is influenced by students' motivations and the quality of this interaction is reflected in academic performance in a positive or negative way (Zimmerman et al., 1992).

When we look at the information in the literature, it is seen that there are other variables that affect academic achievement and academic self-efficacy in a consistent way. At this point, it is necessary to examine the academic self-efficacy beliefs of the students in terms of some variables that are thought to be related to academic selfefficacy. On the other hand, it has been observed that the researches examining the academic self-efficacy levels of university students studying in the field of sports are limited.

In this study, it is aimed to examine the academic self-efficacy of university students studying in the field of sports sciences in terms of gender, university, department, class and place of residence. The research is important in terms of the fact that university students studying in the field of sports at the international and national level are not a subject that is frequently studied in the sample and in this sense they will bring innovation to the literature.

\section{Method}

\subsection{Model of the Research}

Descriptive survey method of research models based on observation was used in this study. This type of research is performed when researchers want to answer the questions they want to find answers and test whether the questions are correct; by developing hypotheses, surveys and scales (Can, 2014).

\subsection{Research Group}

In the 2016-2017 academic year, 386 students from Hitit and Atatürk University Sports Sciences Faculties and Bülent Ecevit and Cumhuriyet University Physical Education and Sports Schools' departments of Physical Education, Sports Management and Coaching Education were enrolled within the scope of the research. In determining the sample size, the sample size of $n=386$ was determined by considering Krejcie and Morgan (1970) 
"Sample Determination Table". The students were selected by convenience sampling method. Information on personal characteristics of students is presented in Table 1.

Table-1. Personal Information of Participants

\begin{tabular}{l|l|l}
\hline Gender & f & $\mathbf{\%}$ \\
\hline Female & 165 & 42,7 \\
\hline Male & 221 & 57,3 \\
\hline University & $\mathbf{f}$ & $\mathbf{\%}$ \\
\hline Hitit University & 121 & 31,3 \\
\hline Bülent Ecevit University & 86 & 22,3 \\
\hline Cumhuriyet University & 87 & 22,5 \\
\hline Atatürk University & 92 & 23,8 \\
\hline Department & $\mathbf{f}$ & $\mathbf{\%}$ \\
\hline Physical Education and Sports Teaching & 286 & 74,1 \\
\hline Sports Management & 57 & 14,8 \\
\hline Coaching Education & 43 & 11,1 \\
\hline Class & $\mathbf{f}$ & $\mathbf{\%}$ \\
\hline 1 & 103 & 26,7 \\
\hline 2 & 146 & 37,8 \\
\hline 3 & 103 & 26,7 \\
\hline 4 & 34 & 8,8 \\
\hline Students' Place of Grows & $\mathbf{f}$ & $\mathbf{\%}$ \\
\hline Village & 61 & 15,8 \\
\hline District & 142 & 36,8 \\
\hline Province & 183 & 47,4 \\
\hline Total & $\mathbf{3 8 6}$ & $\mathbf{1 0 0}$ \\
\hline Source: This table is result of our studies &
\end{tabular}

According to Table 1, the survey participants consisted of 165 women (42.7\%) and 221 men (57.3\%). Although the percentages of the university where the participants were studying were close to each other, the highest participation was from Hitit University with $31.3 \%$ and the lowest with $22.3 \%$ was from Bülent Ecevit University. The majority of the participants were $74.1 \%$ in the department of Physical Education and Sports and $37.8 \%$ in the second year. $47.4 \%$ of the participants stated that they grew up in the province, $36.8 \%$ in the district and $15.8 \%$ in the village.

\subsection{Data Collection Tools}

"Personal Information Form" which was created by the researchers was used in the determination of the personal information of the students. The academic self-efficacy scale developed by Owen and Froman (1988) and studied Turkish validity and reliability by Ekici (2012) was used to determine the academic self-efficacy levels of the students. "Academic Self-Efficacy Scale "consists of 33 themes and 3 sub-dimensions. The scale consists of three sub-dimensions: "Social Status", "Cognitive Practices" and "Technical Skills". 2. 3. 4. 11. 14. 15. 16. 17. 25. and 27. Articles belong to the 'Social Status' sub-dimension, 1, 5, 6, 7, 8, 9, 10, 12, 13, 18, 19, 20, 21, 22, 24, 30, 31,32 and 33 articles to the 'Cognitive Practices' sub-dimension and 23, 26, 28 and 29 articles belong to the 'Technical Skills'. In the Turkish validity and reliability study, the Cronbach Alpha value of the scale was found to be 0,86 . The reliability coefficients of the sub-dimensions were found to be 0.88 in the 'Social Status' sub-dimension, 0.82 in the 'Cognitive Practices' sub-dimension, and 0.90 in the 'Technical Skills' sub-dimension (Ekici, 2012). 174. Data collection tools were applied by the researchers face to face. In practice, participants were required to voluntarily fill data collection tools.

\subsection{Analysis of Data}

SPSS 22 program was used in the analysis of the obtained data and Kolmogorov-Smirnov test was applied to determine whether the data showed normal distribution and the significance level was accepted as 0.05 in the analyses. In the analysis of the data, independent sample $t$ test was applied according to gender variable. One-Way ANOVA test was applied in the analysis of the variables of the university, department, class and place where the participants were studying and LSD test was used to determine the significant difference. Pearson Correlation test was applied to determine the relationship between the academic self-efficacy sub-dimensions.

\section{Findings}

Table-2. Investigation of Academic Self-Efficacy Level by Gender

\begin{tabular}{|c|c|c|c|c|c|c|c|}
\hline Dimensions & Gender & n & $\bar{X}$ & s.s & sd & $\mathbf{t}$ & $\mathbf{p}$ \\
\hline \multirow{2}{*}{ Social Status } & Female & 165 & 34,24 & 5,47 & \multirow{2}{*}{$-0,443$} & \multirow{2}{*}{384} & \multirow{2}{*}{0,658} \\
\hline & Male & 221 & 34,51 & 6,21 & & & \\
\hline \multirow{2}{*}{ Cognitive Practices } & Female & 165 & 63,73 & 11,24 & \multirow{2}{*}{1,445} & \multirow{2}{*}{384} & \multirow{2}{*}{0,149} \\
\hline & Male & 221 & 62,03 & 11,52 & & & \\
\hline \multirow{2}{*}{ Technical Skills } & Female & 165 & 12,50 & 2,96 & \multirow{2}{*}{$-1,198$} & \multirow{2}{*}{384} & \multirow{2}{*}{0,232} \\
\hline & Male & 221 & 12,87 & 2,98 & & & \\
\hline \multirow{2}{*}{ General Academic Self Efficacy } & Female & 165 & 110,47 & 17,18 & \multirow{2}{*}{0,575} & \multirow{2}{*}{384} & \multirow{2}{*}{0,566} \\
\hline & Male & 221 & 109,41 & 18,47 & & & \\
\hline
\end{tabular}

Source: This table is result of our studies. 
Independent sample t-test was applied to determine whether the participants' academic self-efficacy general and sub-dimension levels differed according to gender. According to Table 2; Cognitive Practices (63, 73-62, 03) subdimension and Academic Self-Efficacy general average (110, 47-109, 41) were found to be higher in female participants and there was no significant difference between the academic self-efficacy and sub-dimensions of the students as to gender variable $(\mathrm{t}=384, \mathrm{p}>0.05)$.

\begin{tabular}{|c|c|c|c|c|c|c|c|}
\hline Dimensions & University & $\mathbf{n}$ & $\overline{\boldsymbol{X}}$ & s.s & $\mathbf{F}$ & sd & $\mathbf{p}$ \\
\hline \multirow{4}{*}{ Social Status } & Hitit University & 121 & 35,30 & 5,92 & \multirow{4}{*}{1,378} & \multirow{4}{*}{3} & \multirow{4}{*}{0,249} \\
\hline & Bülent Ecevit University & 86 & 34,00 & 5,60 & & & \\
\hline & Cumhuriyet University & 87 & 33,94 & 5,93 & & & \\
\hline & Atatürk University & 92 & 34,01 & 6,06 & & & \\
\hline \multirow{4}{*}{ Cognitive Practices } & Hitit University & 121 & 63,73 & 12,47 & \multirow{4}{*}{0,890} & \multirow{4}{*}{3} & \multirow{4}{*}{0,446} \\
\hline & Bülent Ecevit University & 86 & 61,12 & 11,14 & & & \\
\hline & Cumhuriyet University & 87 & 62,87 & 10,26 & & & \\
\hline & Atatürk University & 92 & 62,90 & 11,28 & & & \\
\hline \multirow{4}{*}{ Technical Skills } & Hitit University & 121 & 12,81 & 3,09 & \multirow{4}{*}{0,129} & \multirow{4}{*}{3} & \multirow{4}{*}{0,943} \\
\hline & Bülent Ecevit University & 86 & 12,65 & 3,03 & & & \\
\hline & Cumhuriyet University & 87 & 12,57 & 2,71 & & & \\
\hline & Atatürk University & 92 & 12,77 & 3,03 & & & \\
\hline \multirow{4}{*}{$\begin{array}{l}\text { General Academic Self } \\
\text { Efficacy }\end{array}$} & Hitit University & 121 & 111,83 & 19,00 & \multirow{4}{*}{0,903} & \multirow{4}{*}{3} & \multirow{4}{*}{0,440} \\
\hline & Bülent Ecevit University & 86 & 107,77 & 17,34 & & & \\
\hline & Cumhuriyet University & 87 & 109,39 & 16,33 & & & \\
\hline & Atatürk University & 92 & 109,68 & 18,43 & & & \\
\hline
\end{tabular}

Source: This table is result of our studies.

One-Way Anova analysis was performed to determine whether the participants' academic self-efficacy general and sub-dimension levels differed according to the university variable they were studying. According to Table 3, it was found that the Academic Self-Efficacy and Sub-dimensions of the participants did not differ significantly according to the university variable ( $\mathrm{p}>0.05)$.

Table-4. Investigation of Academic Self-Efficacy Level According to Department

\begin{tabular}{|c|c|c|c|c|c|c|c|}
\hline Dimensions & Department & $\mathbf{n}$ & $\overline{\boldsymbol{X}}$ & s.s & $\mathbf{F}$ & sd & $\mathbf{p}$ \\
\hline \multirow{3}{*}{ Social Status } & $\begin{array}{l}\text { Physical Education and Sports } \\
\text { Teaching }\end{array}$ & 286 & 34,44 & 6,04 & \multirow{3}{*}{0,140} & \multirow{3}{*}{3} & \multirow{3}{*}{0,86} \\
\hline & Sports Management & 57 & 34,04 & 5,36 & & & \\
\hline & Coaching Education & 43 & 34,60 & 5,70 & & & \\
\hline \multirow{3}{*}{ Cognitive Practices } & $\begin{array}{l}\text { Physical Education and Sports } \\
\text { Teaching }\end{array}$ & 286 & 62,52 & 11,78 & \multirow{3}{*}{0,331} & \multirow{3}{*}{3} & \multirow{3}{*}{0,718} \\
\hline & Sports Management & 57 & 63,02 & 10,34 & & & \\
\hline & Coaching Education & 43 & 64,00 & 10,47 & & & \\
\hline \multirow{3}{*}{ Technical Skills } & $\begin{array}{l}\text { Physical Education and Sports } \\
\text { Teaching }\end{array}$ & 286 & 12,71 & 3,00 & \multirow{3}{*}{0,200} & \multirow{3}{*}{3} & \multirow{3}{*}{0,802} \\
\hline & Sports Management & 57 & 12,72 & 2,85 & & & \\
\hline & Coaching Education & 43 & 12,72 & 3,02 & & & \\
\hline \multirow{3}{*}{ General Academic Self Efficacy } & $\begin{array}{l}\text { Physical Education and Sports } \\
\text { Teaching }\end{array}$ & 286 & 109,66 & 18,46 & \multirow{3}{*}{0,161} & \multirow{3}{*}{3} & \multirow{3}{*}{0,851} \\
\hline & Sports Management & 57 & 109,77 & 16,67 & & & \\
\hline & Coaching Education & 43 & 111,33 & 16,01 & & & \\
\hline
\end{tabular}

Source: This table is result of our studies.

When Table 4 is examined, it is seen that the One-Way Anova test was conducted to determine whether the Academic Self-Efficacy general and sub-dimension levels differed according to the departments of the university, and the Academic Self-Efficacy and Sub-dimensions of the participants did not show a significant difference according to the departments they studied $(\mathrm{p}>0.05)$.

The One-Way Anova Test was applied to determine whether the academic self-efficacy and sub-dimension levels of the participants differ according to the grade level. According to Table 5, there was a significant difference between Social Status sub-dimension and class level. $(\mathrm{F}=3.316, \mathrm{SD}=3, \mathrm{p}=0.020, \mathrm{p}<0.05)$ Social status levels of $3^{\mathrm{rd}}$ grades were determined to be higher $(\bar{X}=35,81)$ than $2^{\text {nd }}$ grades $(\bar{X}=33,59)$ and $4^{\text {th }}$ grades $(\bar{X}=33,32)$. The LSD test was used to determine the difference between the groups and the difference between the $3^{\text {rd }}$ grades and $2^{\text {nd }}$ and $4^{\text {th }}$ grades was significant. It was found that there was no significant difference between the participants' academic self-efficacy general, cognitive practices sub-dimension and technical skills sub-dimension ( $\mathrm{p}>0.05)$. 
Table-5. Investigation of Academic Self-Efficacy Level According to Class Level

\begin{tabular}{|c|c|c|c|c|c|c|c|c|}
\hline Dimensions & Class & $\mathbf{n}$ & $\overline{\boldsymbol{X}}$ & s.s & $\mathbf{F}$ & sd & $\mathbf{p}$ & Difference \\
\hline \multirow{4}{*}{ Social Status } & 1 & 103 & 34,49 & 5,74 & \multirow{4}{*}{3,316} & \multirow{4}{*}{3} & \multirow{4}{*}{$0,020^{*}$} & \multirow{4}{*}{$\begin{array}{l}3-2 \\
3-4\end{array}$} \\
\hline & 2 & 146 & 33,59 & 6,22 & & & & \\
\hline & 3 & 103 & 35,81 & 5,19 & & & & \\
\hline & 4 & 34 & 33,32 & 6,36 & & & & \\
\hline \multirow{4}{*}{ Cognitive Practices } & 1 & 103 & 63,37 & 12,31 & \multirow{4}{*}{0,556} & \multirow{4}{*}{3} & \multirow{4}{*}{0,644} & \\
\hline & 2 & 146 & 61,98 & 11,42 & & & & \\
\hline & 3 & 103 & 63,54 & 10,23 & & & & \\
\hline & 4 & 34 & 61,85 & 12,27 & & & & \\
\hline \multirow{4}{*}{ Technical Skills } & 1 & 103 & 12,53 & 2,73 & \multirow{4}{*}{0,465} & \multirow{4}{*}{3} & \multirow{4}{*}{0,707} & \\
\hline & 2 & 146 & 12,74 & 3,08 & & & & \\
\hline & 3 & 103 & 12,95 & 2,88 & & & & \\
\hline & 4 & 34 & 12,41 & 3,47 & & & & \\
\hline \multirow{4}{*}{ General Academic Self Efficacy } & 1 & 103 & 110,39 & 18,52 & \multirow{4}{*}{1,217} & \multirow{4}{*}{3} & \multirow{4}{*}{0,303} & \\
\hline & 2 & 146 & 108,31 & 18,56 & & & & \\
\hline & 3 & 103 & 112,30 & 15,66 & & & & \\
\hline & 4 & 34 & 107,59 & 19,44 & & & & \\
\hline
\end{tabular}

Source: This table is result of our studies.

Table-6. Investigation of Academic Self-Efficacy Level According to Students' Place of Grew Up

\begin{tabular}{|c|c|c|c|c|c|c|c|c|}
\hline Dimensions & $\begin{array}{l}\text { Students' Place of } \\
\text { Grew Up }\end{array}$ & $\mathbf{n}$ & $\bar{X}$ & s.s & $\mathbf{F}$ & sd & $\mathbf{p}$ & Difference \\
\hline \multirow{3}{*}{ Social Status } & Village & 61 & 33,08 & 6,21 & \multirow{3}{*}{1,808} & \multirow{3}{*}{2} & \multirow{3}{*}{0,165} & \\
\hline & District & 142 & 34,65 & 5,94 & & & & \\
\hline & Province & 183 & 34,63 & 5,73 & & & & \\
\hline \multirow{3}{*}{ Cognitive Practices } & Village & 61 & 61,20 & 9,33 & \multirow{3}{*}{0,805} & \multirow{3}{*}{2} & \multirow{3}{*}{0,448} & \\
\hline & District & 142 & 63,42 & $12, \mathrm{OO}$ & & & & \\
\hline & Province & 183 & 62,77 & 11,59 & & & & \\
\hline \multirow{3}{*}{ Technical Skills } & Village & 61 & 11,62 & 2,72 & \multirow{3}{*}{5,347} & \multirow{3}{*}{2} & \multirow{3}{*}{$0,005^{* *}$} & \\
\hline & District & 142 & 12,76 & 2,92 & & & & $1-2$ \\
\hline & Province & 183 & 13,04 & 3,02 & & & & \\
\hline \multirow{3}{*}{$\begin{array}{l}\text { General Academic Self } \\
\text { Efficacy }\end{array}$} & Village & 61 & 105,90 & 16,37 & \multirow{3}{*}{1,800} & \multirow{3}{*}{2} & \multirow{3}{*}{0,167} & \\
\hline & District & 142 & 110,83 & 18,38 & & & & \\
\hline & Province & 183 & 110,44 & 17,96 & & & & \\
\hline
\end{tabular}

Source: This table is result of our studies.

When Table 6 is examined, it is seen that the One-Way Anova Test was conducted to determine whether the academic self-efficacy general and sub-dimension levels of the participants differ according to where their place of grew up. The level of efficacy in the Technical Skills sub-dimension shows a significant difference according to the type of place of grew up. $(\mathrm{F}=5,347, \mathrm{SD}=3, \mathrm{p}=0.005, \mathrm{p}<0.01)$ In the Technical Skills sub-dimension, the participants who were village-grown were found to have lower levels of efficacy $(\bar{X}=11,62)$ compared to district $(\bar{X}=12,76)$ and province $(\bar{X}=13,04)$. In order to determine the differences between the groups, the LSD test from post hoc tests was performed and the difference between the first group (village) and 2nd (district) and 3rd (province) groups was found significant. It was determined that there was no significant difference between the participants' academic self-efficacy general, social status and cognitive practices sub-dimensions and the place where students grew up $(\mathrm{p}>0.05)$.

\section{Discussion and Conclusion}

In this study, the academic self-efficacy of university students studying in the field of sports is examined; It was determined that academic self-efficacy belief levels of students did not differ significantly according to gender variable. This result is consistent with Sahin and Çakar (2011) studies on $4^{\text {th }}$ grade undergraduate students and the studies of Demir and Arı (2013) on primary school teacher candidates. In another study on non-thesis master degree students; Azar (2010) concluded that academic self-efficacy beliefs did not show a significant difference according to gender. However, there are studies in the literature that do not show consistency with the results of this research (Biricik, 2015; Yağcl and Aksoy, 2015). Tschannen-Moran and Hoy (2001) stated that variables within the school have a feature that determines self-efficacy more effectively than students' demographics.

In this study, it was determined that the academic self-efficacy levels of the students did not show a significant difference according to the education grade. There are no significant differences in the grade level, because it can be thought that the fact that students are in similar developmental periods although they are in different classes, have entered with similar academic achievement level and have similar motivational status. The findings of the class variable of this study are not consistent with the literature. In the literature, it was reported that academic selfefficacy levels of university students differed significantly according to the class variable (Firat-Durdukoca, 2010; Ağgül-Yalçın, 2011) and that the academic self-efficacy levels of the students increased as the grade level increased (Yaman et al., 2004; Avara, 2015).

It was determined that the academic self-efficacy levels of the students who participated in the study did not show a significant difference according to the department variable. Even though the students have to study in different departments, it can be thought in the emergence of this result that the students take the special talent exam and get similar education. There are similar studies in the literature that academic self-efficacy levels differed according to the department variable (Ŏguz, 2012; Alemdağ et al., 2014; Koçer, 2014; Biricik, 2015; Yağcl and Aksoy, 2015; Pekel, 2016). 
It was determined that the students had a significant difference according to their place of grew up. According to the findings, in 'Technical Skills' sub-dimension, it was determined that self-efficacy level of the students who were raised in the district or province was higher than the students who were educated in the village. In the literature, no positive or negative consistency was found with the results of this study. The basis of this result is that the academic equipment of the students who were educated in the village were lower compared to the students who were educated in the provinces and districts and the low level of education they received before the university may be considered. This finding also suggests that social life in large cities may affect learning and indirectly contribute to academic self-efficacy belief.

In this study, the academic self-efficacy of university students studying in the field of sports is examined; It was concluded that the academic self-efficacy levels of the students showed a significant difference according to the place of residence; however, showed no significant differences as to gender, university, department and class variables. According to these findings, it can be said that socio-demographic variables are not a significant determinant of the academic self-efficacy levels of the students studying in the field of sports science.

It is gratifying that showing no differences in their academic self-efficacy according to gender, university, department and class for the university students who are studying in the field of sports sciences, at the point of reaching the goal of the trainings which are given. However, it is thought-provoking that academic self-efficacy differs according to the place where the students grow up. Therefore, it is considered that the public and private institutions carrying out academic activities in the settlements should aim at self-efficacy development by implementing activities that will contribute to their academic self-efficacy. In cases where these institutions are insufficient, local governments can also be expected to organize activities to support education. The research can be repeated with different variables, limitations and samples.

\section{References}

Ağgül-Yalçın, F., 2011. Investigation of science teacher candidates' self-efficacy beliefs of science teaching with respect to some variables. International Online Journal of Educational Sciences, 3(3): 1046-1063.

Alemdă̆, C., E. Öncü and A.K. Yılmaz, 2014. Preservice physical education teachers' academic motivation and academic self-efficacy. Hacettepe University Journal of Sport Sciences, 25(1): 23-35.

Avara, K., 2015. Academic self - efficacy, career decision making self - efficacy and school burnout as predictor of academic motivation in high school student. Unpublished Master Thesis. Mevlana University, Konya, Turkey.

Azar, A., 2010. In-service and pre-service secondary science teachers self-efficacy beliefs about science teaching. Educational Research and Reviews, 5(4): 172-185.

Bandura, A., 1982. Self-efficacy mechanism in human agency. American Psychologist, 37(2): 122-147. Available at: https://doi.org/10.1037/0003-066x.37.2.122.

Bandura, A., 1997. Self efficacy: The exercise of control. New York: W. H. Freeman.

Bassi, M., P. Steca, A. Delle Fave and G.V. Caprara, 2007. Academic self-efficacy beliefs and quality of experience in learning. Journal of Youth and Adolescence, 36(3): 301-312. Available at: https://doi.org/10.1007/s 10964-006-9069-y.

Belgi, S., 2016. To researchïng the self-sufficiency of hïgh school counselors and the burnout of hïgh school counselors. Unpublished Master Thesis. Nişantaşı University, İstanbul, Turkey.

Biricik, Y., 2015. The study of academic self-sufficiency of the students studying in the departments of physical education and sports. Unpublished Master Thesis, Atatürk University, Erzurum, Turkey.

Can, A., 2014. Quantitative data analysis in scientific research process with SPSS. 2nd Edn., Ankara: Pegem Academy.

Çubukçu, Z. and P. Girmen, 2007. Determining the social self-efficacy perception of candidate teachers. Eskişehir Osmangazi University Journal of Social Sciences, $8(1): 57-74$.

Demir, M.K. and E. Arı, 2013. Assessing levels of academic motivation of preservice teachers in terms of various variables. Journal of Theory and Practice in Education, 9(3): 265-279.

Edmonds, H.K., 2002. Grade retention and children's academic self-efficacy and use of self-protective strategies. Doctoral Thesis, Wayne State University, Detroit, USA.

Ekici, G., 2012. Academic self efficacy scale: The study of adaption to Turkish, validity and reliability. Hacettepe University Journal of Education, 43(1): 174-185.

Firat-Durdukoca, Ş., 2010. Analysis of academic self-efficiency beliefs of elementary school teacher candidates using different variables. Journal of Abant İzzet Baysal University, $10(1): 69-77$.

İpek, C. and C. Bayraktar, 2009. Self-efficacy perceptions of pre-service primary teachers on physical education. Ahi Evran University Jounal of Education, $10(2): 67-84$.

Kandemir, M. and Y. Özbay, 2012. Academic self-efficacy scale: Validity reliability study. Journal of Education Faculty, 14(2): 201-214.

Koçak, F., 2017a. The relationship between leisure constraints, constraint negotiation strategies and facilitators with recreational sport activity participation of college students. College Student Journal, 51(4): 491-497.

Koçak, F., 2017b. Lesure constraints and faciltators: Perspectives from Turkey. European Journal of Physical Education and Sport Science, 3(10): $32-47$.

Koçer, M., 2014. A study of the relationship between academic self-efficacy and self-concept of secondary school students: A case study in Zonguldak Province. Unpublished Master Thesis. Dokuz Eylül University: İzmir, Turkey.

Krejcie, R.V. and D.W. Morgan, 1970. Determining sample size for research activities. Educational and Psychological Measurement, 30(3): 607-610. Available at: https://doi.org/10.1177/001316447003000308.

Kurbanoğlu, S., 2004. Self-efficacy belief and its importance for information professionals. Information World, 5(2): 137-152.

Oğuz, A., 2012. Academic self-efficacy beliefs of prospective primary school teachers. Anadolu Journal of Educational Sciences International, 2(2): 15-28.

Owen, S. and R.D. Froman, 1988. Development of a college academic self-efficacy scale. Annual Meeting of the National Council on Measurement in Education. LA. New Orleans.

Pekel, A., 2016. Investigation of academic self-efficacy and relationship between the quality of university life of students studying sport management departments. Unpublished Master Thesis, Erciyes University, Kayseri, Turkey.

Sahin, H. and E. Çakar, 2011. The effect of learning strategies and academic motivation levels of the faculty of education students on the academic achievements. Journal of Turkish Education Science, 9(3): 519-540.

Schunk, D.H., 1991. Self-efficacy and academic motivation. Educational Psychologist, 26(3-4): 207-231. Available at: https://doi.org/10.1080/00461520.1991.9653133.

Schwarzer, K.R. and S. Hallum, 2008. Perceived teacher self-efficacy as a predictor of job stress and burn out: Mediation analyses. Applied Psychology, 57(1): 152-171.

Tschannen-Moran, M. and A.W. Hoy, 2001. Teacher efficacy: Capturing an elusive construct. Teaching and Teacher Education, 17(7): 783805. Available at: https://doi.org/10.1016/s0742-051x(01)00036-1.

Wood, R. and A. Bandura, 1989. Social cognitive theory of organizational management. Academy of Management Review, 14(3): 361-384. Available at: https://doi.org/10.2307/258173.

Yağcı, U. and V. Aksoy, 2015. An analysis of the relationship between academic self-efficacy and teaching self-efficacy of pre-service music teachers. MAKU Journal of Faculty of Education, 1(33): 84-104. 
Yaman, S., Ö.C. Koray and A. Altunçekiç, 2004. A study on the examination of self-efficacy belief levels of science teacher candidates. Journal of Turkish Education Science, 2(3): 355-366.

Zimmerman, B.J., A. Bandura and M. Martinez-Pons, 1992. Self-motivation for academic attainment: The role of self-efficacy beliefs and personal goal setting. American Educational Research Journal, 29(3): 663-676. Available at: https://doi.org/10.3 102/00028312029003663. 